\title{
THE INFLUENCE OF NUTRITION ON RAINBOW TROUT (ONCORHYNCHUS MYKISS) MEAT QUALITY
}

\author{
D. Vranić ${ }^{1}$, D. Trbović ${ }^{1}$ J. Djinović-Stojanović ${ }^{1}$, R. Baltić ${ }^{2}$, M. \\ Milijašević $^{1}$, S. Lilić ${ }^{1}$, A. Spirić ${ }^{1}$ \\ ${ }^{1}$ Institute of Meat Hygiene and Technology, Kacanskog 13, 11000 Belgrade, Republic of Serbia \\ ${ }^{2}$ Faculty of Veterinary Medicine, Bulevar oslobođenja 18, 11000 Belgrade, Republic of Serbia \\ Corresponding author: aurelija@inmesbgd.com \\ Communication
}

\begin{abstract}
Feed of high quality is one of the most important parameter which influences fish growth, feed conversion and chemical composition of fish meat in conditions of intensive fish farming. Studies on the influence of two commercial diets on nutritional quality and production results in rainbow trout intensive farming conditions in Pond I and Pond II were undertaken. Obtained values for proteins and fats in feed were significantly higher $(p<0.001)$ in Diet II comparing to Diet I. The average water and ash content was significantly higher $(p<0.001)$ in Diet I in relation to Diet II. The average length and mass of fish were higher in Pond I in relation to Pond II. Calculated values for condition factors, $\mathrm{K}_{\mathrm{f}}$, indicate to a higher production results in Pond II (1.81) in relation to Pond I (1.22). There were not significant differences $(\mathrm{p}>0.05)$ in the average content of proteins and ash in fillets of fish from Pond I (17.43\% and 1.19\%, respectively) and Pond II (18.69\% and $1.29 \%$, respectively). The average content of water was significantly higher $(\mathrm{p}<0.001)$ in fillets of fish from Pond I $(79.87 \%)$ comparing to fillets of fish from Pond II (75.40\%). Average content of fat in fillets of trout from Pond II $(4.17 \%)$ was around three times higher than the average content of fat in fillets of trout from Pond I (1.41\%), ( $<<0.001)$. Results for energy values $(348.44 \mathrm{~kJ} / 100 \mathrm{~g}$ Pond I and $471.38 \mathrm{~kJ} / 100 \mathrm{~g}$ - Pond II) are in a direct correlation with the content of fat in fish. The average content of cholesterol in fillets of trout from Pond II (70.12 $\mathrm{mg} / 100 \mathrm{~g})$ was significantly higher $(\mathrm{p}<0.001)$ than in fillets of trout from Pond I $(44.11 \mathrm{mg} / 100 \mathrm{~g})$. The obtained data indicate to a positive influence of fat content in the diet on fat content, energy value and production results in rainbow trout production in Pond II. Lower water temperature established in Pond II $\left(8^{\circ} \mathrm{C}\right)$ comparing to Pond $\mathrm{I}\left(13^{\circ} \mathrm{C}\right)$ might have had additional influence on the nutritional quality and production results in Pond II, as well.
\end{abstract}

Key words: rainbow trout, diet, proximate composition, production results, condition factor, cholesterol content. 


\section{Introduction}

Nutritional and health benefits achieved by consumption of fish have changed populations' habits regarding fish consumption. That increased production and consumption of fish from aquaculture and imposed certain requirements to its' quality and nutritional value (Burger and Gochfeld, 2009). Low fat content, proteins of high biological value and relatively low cholesterol content as well as valuable quantities of essential fatty acids makes rainbow trout (Oncorhynchus mykiss) one of the most appreciable fish in human nutrition (Conor, 2000; Sidhu, 2003).

In conditions of intensive fish farming proper nutrition by offering suitable quantities of high-quality feed is the most important parameter which influences fish growth, feed conversion and chemical composition of fish meat (Valente et al., 2007; Almeida et al., 2011). In spite of that, salmonid fish species, where belong rainbow trout too, are the most demanding ones. Nutrition may affect, not only the ratio of proteins, fat and water, but the nutritional value of meat as well and the fatty acid composition (Caballero et al., 2002). However, nutritional quality of fish might be influenced by genetic factors, $\mathrm{pH}$, oxygen content, water temperature and water quality, type of feed and feeding technology, etc. (Skalli et al., 2006; Dube and Hosetti, 2010).

Except highly digestible proteins and valuable fats fish contain cholesterol which might be unfavorable to human health. Literature data indicate that fish from aquaculture, although contain higher fat content than the same fish species from open waters, they contain similar quantities of cholesterol when expressed as $\mathrm{g} / 100 \mathrm{~g}$ fillets (Cahu et al, 2004). Other data indicate that cholesterol content in freshwater fish depends more on fish species than on type of rearing (Moreira et al., 2001). Considering clinical and epidemiological studies which point out to the connection between cholesterol in food, cholesterol in blood plasma and arteriosclerosis, relatively low content of cholesterol, makes trout a very suitable fish species for human consumption (Orban et al., 2006).

Annual consumption of fish in Serbia is around $7 \mathrm{~kg}$ per capita (Baltic et al., 2009). There are many reasons for such a low consumption, as leak in habits of eating fish, insufficient production, irregular market supply and orientation to import, week offer of diverse types of fish, high prices, leak of knowledge on consuming healthy food, etc. It is reliable that national production in aquaculture is insufficient and is mainly related to carp (Cyprinus carpio), over $80 \%$, and rainbow trout (Oncorhynchus mykiss) production, around 15\% (Trbović et al., 2009; Vranić et al., 2011). With the aim of contributing to development of aquaculture in the country, the objectives of this study were to investigate the influence of nutrition (two different commercial diets) on rainbow trout meat quality parameters 
(proximate composition and cholesterol content) and production results in rainbow trout intensive farming conditions, as well.

\section{Materials and Methods}

\section{Animals and sampling}

Rainbow trout samples (Oncorhynchus mykiss) were collected during summer season from two intensive fish ponds (Pond I and Pond II) situated on different geographic locations. Fish ponds were supplied with water of potable quality directly from the springs. Water temperature in fish ponds was constant during the year, but different one in relation to other (Pond I- $13^{\circ} \mathrm{C}$, Pond II- $8^{\circ} \mathrm{C}$ ). Fish was manually fed commercially available extruded sinking pelleted diets (Diet I and Diet II) according to good aquaculture practice. Based on specifications, diet I consisted of fish meal $(27.0 \%)$, chops after soybean extraction $(22.0 \%)$, wheat $(10.0 \%)$, soybean protein concentrate $(7.8 \%)$, extruded soybean seed $(7.0 \%)$, rapeseed chops $(5.3 \%)$, rapeseed, fish and palm oils, corn gluten, amino acids byproducts, organic weat, minerals and vitamins. Diet II consisted of fish products $(60.0 \%)$, oils and fats $(17.5 \%)$, products and by-products of weat $(14.0 \%)$, products and by-products of oil seeds (6.5\%) and vitamin premixes (2\%). During sampling, six fishes were collected from each pond along with the appropriate feed $(n=6)$. Fillets of fish, obtained after evisceration and previous deprivation of skin, tail, head, fins and bones were homogenized in a laboratory blender (Braun CombiMax 600 ), separately placed in plastic bags and stored at $-25^{\circ} \mathrm{C}$ until analyzed. A day before analysis samples were defrosted overnight, at $+4^{\circ} \mathrm{C}$.

\section{Chemicals and standards}

Pro analysis quality and HPLC-grade solvents were obtained from Merck (Darmstadt, Germany) and Sigma Aldrich (Germany). All glassware was rinsed with acetone and hexane. Solvent blanks were analyzed with each lot of reagents. More detailed data on proximate composition determination and saponification method for cholesterol determination by HPLC has been presented in our previous publication (Spirić et al., 2009).

A brief review of proximate composition (proteins, water, lipids and ash) and cholesterol determination is presented below.

\section{Physical parameters of fish}

After reception, mass of fish was measured on a technical balance, with $\pm 0.01 \mathrm{~g}$ accuracy. Fish length, from the tip of the head to the end of the tail, was measured by ruler, with $\pm 0.1 \mathrm{~cm}$ accuracy. 
Condition factor $\left(\mathrm{K}_{\mathrm{f}}\right)$ has been calculated from the average values for length and mass of fish by applying the following equation: $K_{f}=100 \cdot m \cdot l^{-3}$, where is: $\mathrm{m}$-mass of the fish, in $\mathrm{g}$ and l-length of the fish, in $\mathrm{cm}$.

Proximate composition (proteins, water, lipids and ash) determination

Proximate composition of fish fillets and feed was determined by ISO and in-house validated methods. Protein content was determined by Kjeldahl $-\mathrm{N} * 6.25$ (Kjeltec Auto 1030 Analyzer, Tecator, Sweeden). Water content was determined by drying at $103 \pm 2^{\circ} \mathrm{C}$ to constant weight. For determination of total fat, samples were hydrolyzed with $4 \mathrm{M}$ hydrochloric acid and extracted with petroleum ether by Soxhlet apparatus. Ash was determined by combustion at $550 \pm 25^{\circ} \mathrm{C}$.

\section{Cholesterol determination by HPLC}

Cholesterol content was determined, after direct saponification of fish muscle at $80^{\circ} \mathrm{C}$, by Waters $2695 \mathrm{HPLC} / \mathrm{PDA}$ system, on a Phenomenex Luna C18 reverse phase column, at $210 \mathrm{~nm}$. Quantification was performed by external standardization in a linear concentration range from $25 \mathrm{mg} / 100 \mathrm{~g}$ to $125 \mathrm{mg} / 100 \mathrm{~g}$. Recoveries of the spiked quantities ranged from 66.30 to $74.80 \%$.

\section{Statistical analysis}

For data analysis UnscramblerX statistical software (CamoSoft, Norway) was used. Means within each group were compared with ANOVA and Tukey Kramer's multiple range tests.

\section{Results and Discussion}

Proximate composition (protein, water, fat and ash) of commercial diets for trout breed in Pond I and Pond II is presented in Table 1. The obtained data indicate that the average values for proteins and fats were significantly higher, ( $\mathrm{p}<0.001)$, in Diet II $(44.81 \pm 0.11 \%$ and $25.33 \pm 0.09 \%$, respectively) comparing to Diet I ( $42.60 \pm 0.04 \%$ and $18.08 \pm 0.04 \%$, respectively). The average water and ash content was significantly higher, $(\mathrm{p}<0.001)$, in Diet $\mathrm{I} \quad(7.41 \pm 0.02 \%$ and $8.18 \pm 0.14 \%$, respectively) in relation to Diet II $(6.40 \pm 0.03 \%$ and $4.87 \pm 0.05 \%$, respectively). It was demonstrated that feed of high quality is one of the most important parameter which influences fish growth, feed conversion and chemical composition of fish meat in conditions of intensive fish farming (Caballero et al., 2002; Valente et al., 2007). 
Table 1. Protein, water, fat and ash content (\%, wet weight basis) in commercial diets for trout

\begin{tabular}{|c|c|c|c|c|c|c|c|}
\hline \multirow{3}{*}{ Parameter } & \multirow{3}{*}{ Pond } & \multirow{3}{*}{$\mathrm{X}$} & \multicolumn{5}{|c|}{ Measures of dispersion } \\
\hline & & & \multirow[t]{2}{*}{$\mathrm{Sd}$} & \multirow[t]{2}{*}{$\mathrm{Se}$} & \multicolumn{2}{|c|}{ Iv } & \multirow[t]{2}{*}{$\mathrm{CV}(\%)$} \\
\hline & & & & & $\mathrm{X}_{\min }$ & $\mathrm{X}_{\max }$ & \\
\hline \multirow[t]{2}{*}{ Protein } & I & $42.60^{\alpha}$ & 0.04 & 0.02 & 42.55 & 42.65 & 0.09 \\
\hline & II & $44.81^{\beta}$ & 0.11 & 0.05 & 44.64 & 44.96 & 0.25 \\
\hline \multirow[t]{2}{*}{ Water } & $\mathrm{I}$ & $7.41^{\alpha}$ & 0.02 & 0.01 & 7.39 & 7.44 & 0.26 \\
\hline & II & $6.40^{\beta}$ & 0.03 & 0.01 & 6.36 & 6.44 & 0.43 \\
\hline \multirow[t]{2}{*}{ Fat } & I & $18.08^{\alpha}$ & 0.04 & 0.02 & 18.01 & 18.12 & 0.22 \\
\hline & II & $25.33^{\beta}$ & 0.09 & 0.04 & 25.21 & 25.42 & 0.34 \\
\hline \multirow[t]{2}{*}{ Ash } & I & $8.18^{\alpha}$ & 0.14 & 0.06 & 8.02 & 8.32 & 1.67 \\
\hline & II & $4.87^{\beta}$ & 0.05 & 0.02 & 4.81 & 4.94 & 1.06 \\
\hline
\end{tabular}

${ }^{\alpha, \beta}(\mathrm{p}<0,001)$

The obtained production results for trout breed in Pond I and II, feed two different commercial diets, are presented in Table 2.

Table 2. Production results for marketable trout

\begin{tabular}{|c|c|c|c|c|c|c|c|}
\hline \multirow{3}{*}{ Parameter } & \multirow{3}{*}{ Pond } & & \multicolumn{5}{|c|}{ Measures of dispersion } \\
\hline & & \multirow{2}{*}{$\mathrm{X}$} & \multirow[t]{2}{*}{$\mathrm{Sd}$} & \multirow[t]{2}{*}{$\mathrm{Se}$} & \multicolumn{2}{|c|}{ Iv } & \multirow[t]{2}{*}{ CV (\%) } \\
\hline & & & & & $X_{\min }$ & $\mathrm{X}_{\max }$ & \\
\hline \multirow[t]{2}{*}{ Lenght $(\mathrm{cm})$} & I & $28.22^{\alpha}$ & 0.66 & 0.27 & 27.30 & 29.00 & 2.36 \\
\hline & II & $23.28^{\beta}$ & 1.06 & 0.43 & 22.00 & 24.50 & 4.55 \\
\hline \multirow[t]{2}{*}{ Mass of fish (g) } & $\mathrm{I}$ & 273.33 & 37.24 & 15.20 & 225.00 & 315.00 & 13.62 \\
\hline & II & 228.83 & 41.38 & 16.89 & 170.00 & 290.00 & 18.08 \\
\hline \multirow{2}{*}{$\begin{array}{l}\text { Mass of fillets } \\
(\mathrm{g})\end{array}$} & I & 93.33 & 24.63 & 10.06 & 65.00 & 130.00 & 26.39 \\
\hline & II & 97.26 & 18.22 & 7.44 & 65.57 & 121.41 & 18.73 \\
\hline
\end{tabular}

${ }^{\alpha, \beta}(\mathrm{p}<0,001)$

As it can be seen from the presented results, the average length and mass of fish were higher in Pond I (28.22 $\pm 0.66 \mathrm{~cm}$ and $273.33 \pm 37.24 \mathrm{~g}$, respectively) in relation to Pond II $(23.28 \pm 1.06 \mathrm{~cm}$ and $228.83 \pm 41.38 \mathrm{~g}$, respectively). However, significant difference was established in relation to the average length of fish $(p<0.001)$ only. Difference in the average mass of fish was not significant $(p>0.05)$. The average mass of fillets in fish from Ponds I and II was $93.33 \pm 24.63$ and $97.26 \pm 18.22 \mathrm{~g}$, respectively and no significant difference was established ( $>0.05)$. Even the average length and mass of fish were higher in Pond I in relation to Pond II, the obtained values for condition factors, $\mathrm{K}_{\mathrm{f}}$, (Table 3.) indicate to a higher production results in Pond II (1.81) in relation to Pond I (1.22). Higher production results in Pond II might be influenced by differences in types and share of feed ingredients, as established in the study conducted by De Francesco et al. (2004). They demonstrated that higher $\mathrm{K}_{\mathrm{f}}$, lower mass and length was established in trout 
fed feed containing higher share of maize, wheat and rapeseed meal comparing to trout predominantly fed feed containing fish meal.

Table 3. Condition factor $\left(K_{\mathrm{f}}\right)$ for marketable trout

\begin{tabular}{|l|l|l|}
\hline Parameter & Pond & $\overline{\mathrm{X}}$ \\
\hline Kondition faktor $\left(\mathrm{K}_{\mathrm{f}}\right)$ & $\mathrm{I}$ & 1.22 \\
\cline { 2 - 3 } & II & 1.81 \\
\hline
\end{tabular}

Results for proximate composition (protein, water, fat and ash content) of marketable trout fillets are presented in Table 4.

Table 4. Protein, water, fat and ash content (\%, wet weight basis) in marketable trout fillets

\begin{tabular}{|c|c|c|c|c|c|c|c|}
\hline \multirow{3}{*}{ Parameter } & \multirow{3}{*}{ Pond } & \multirow{3}{*}{$\mathrm{X}$} & \multicolumn{5}{|c|}{ Measures of dispersion } \\
\hline & & & \multirow[t]{2}{*}{$\mathrm{Sd}$} & \multirow[t]{2}{*}{$\mathrm{Se}$} & \multicolumn{2}{|c|}{ IV } & \multirow[t]{2}{*}{$\mathrm{CV}(\%)$} \\
\hline & & & & & $\mathrm{X}_{\min }$ & $\mathrm{X}_{\max }$ & \\
\hline \multirow{2}{*}{ Protein } & I & 17.43 & 1.33 & 0.54 & 15.76 & 19.23 & 7.66 \\
\hline & II & 18.69 & 0.46 & 0.19 & 17.95 & 19.32 & 2.48 \\
\hline \multirow[t]{2}{*}{ Water } & $\mathrm{I}$ & $79.87^{\alpha}$ & 2.13 & 0.87 & 76.55 & 82.03 & 2.67 \\
\hline & II & $75.40^{\beta}$ & 1.14 & 0.46 & 74.38 & 77.36 & 1.51 \\
\hline \multirow[t]{2}{*}{ Fat } & I & $1.41^{\alpha}$ & 0.70 & 0.29 & 0.63 & 2.45 & 49.75 \\
\hline & II & $4.17^{\beta}$ & 0.51 & 0.21 & 3.20 & 4.75 & 12.34 \\
\hline \multirow[t]{2}{*}{ Ash } & I & 1.19 & 0.15 & 0.06 & 1.03 & 1.36 & 12.23 \\
\hline & II & 1.29 & 0.02 & 0.01 & 1.26 & 1.31 & 1.39 \\
\hline
\end{tabular}

The presented results indicate that there were not significant differences ( $>0.05)$ in the average content of proteins and ash in fillets of marketable trout in Pond I $(17.43 \pm 1.33 \%$ and $1.19 \pm 0.15 \%$, respectively) and Pond II $(18.69 \pm 0.46 \%$ and $1.29 \pm 0.02 \%$, respectively). The average content of water was significantly higher $(\mathrm{p}<0.001)$ in fillets of fish from Pond I $(79.87 \pm 2.13 \%)$ than in fillets of fish from Pond II (75.40 $\pm 1.14 \%)$. The average fat content in fillets of trout in Pond II $(4.17 \pm 0.51 \%)$ was around three times higher than the average fat content in fillets of trout in Pond I $(1.41 \pm 0.70 \%),(p<0.001)$. It was established that fat content in fish is in a direct correlation with the nature and content of fat in the diet and that water content in fish flesh is inverse proportional to fat content (Kaushik, 1995). Fat content in marketable trout fillets was independent on the protein content in the diet (Pond I-42.60\%, Pond II-44.81\% proteins), what is in agreement with the data reported by Lupatsch et al. (2001). According to their results, fat content in feed had influence on the fat content in fish, while content of proteins in feed had no influence on protein content in fish. Protein content in salmonidaes is correlated with the size of fish and it is endogenously controlled, while their fat content is 
influenced by numerous endogenous and exogenous factors (Shearer, 1994). Energy values for marketable trout fillets are presented in Table 5. The obtained results indicate that energy values for marketable trout fillets are statistically significantly higher $(\mathrm{p}<0.001)$ in fillets of fish from Pond II $(471.38 \mathrm{~kJ} / 100 \mathrm{~g})$ in relation to fillets of fish from Pond I $(348.44 \mathrm{~kJ} / 100 \mathrm{~g})$. These results are in a direct correlation with the content of fat in fish $(1.41 \%$ fat in fillets of fish from Pond I and $4.17 \%$ fat in fillets of fish from Pond II). The increased energy value of feed increases the content of fat and decrease the content of water in fish (Médale, 2010).

Haliloglu and Aras (2002) and Skalli et al. (2006) demonstrated that nutritional quality of fish, except diet and other factors, might be influenced by water temperature as well. Our data confirm the positive influence of fat content in the diet on fat content and energy value of the fish. However, lower water temperature established in Pond II $\left(8^{\circ} \mathrm{C}\right)$ comparing to Pond I $\left(13^{\circ} \mathrm{C}\right)$ might have had some additional impact on fat content in muscle tissue of fish from Pond II, as well. Martinez et al. (1992) reported that temperature was the factor which had the strongest influence on fat and water content in body composition of rainbow trout.

Table 5. The energy value of marketable trout fillets

\begin{tabular}{|c|c|c|c|c|c|c|c|}
\hline \multirow{3}{*}{ Energy value } & \multirow{3}{*}{ Pond } & \multirow{3}{*}{$\bar{X}$} & \multicolumn{5}{|c|}{ Measures of dispersion } \\
\hline & & & \multirow[t]{2}{*}{$\mathrm{Sd}$} & \multirow[t]{2}{*}{$\mathrm{Se}$} & \multicolumn{2}{|c|}{$\mathrm{Iv}$} & \multirow[t]{2}{*}{ CV (\%) } \\
\hline & & & & & $X_{\min }$ & $X_{\max }$ & \\
\hline $\mathrm{kJ} / 100 \mathrm{~g}$ & I & $348.44^{\alpha}$ & 44.19 & 16.47 & 298.25 & 417.53 & 11.58 \\
\hline $\mathrm{kJ} / 100 \mathrm{~g}$ & II & $471.38^{\beta}$ & 24.88 & 9.27 & 423.51 & 493.60 & 4.82 \\
\hline
\end{tabular}

Results for cholesterol content in fillets of marketable trout are presented on Table 6. The average cholesterol content in fillets of marketable trout from Pond II $(70.12 \mathrm{mg} / 100 \mathrm{~g})$ was significantly higher $(\mathrm{p}<0.001)$ than in fillets of fish from Pond I ( $44.11 \mathrm{mg} / 100 \mathrm{~g})$. Cholesterol content we established for Oncorhynchus mykiss is in accordance with the data obtained by Kopicova and Vavreinova (2007), of $41 \mathrm{mg} / 100 \mathrm{~g}$, for Salmo trutta, Piironen et al. (2002), of $60-65 \mathrm{mg} / 100 \mathrm{~g}$, for Salmo garinderi and Nettleton and Exler (1992), of $60 \mathrm{mg} / 100 \mathrm{~g}$, for Oncorhynchus mykiss.

Table 6. Cholesterol content (mg/100 g, wet weight basis) in fillets of marketable trout

\begin{tabular}{|c|c|c|c|c|c|c|c|}
\hline \multirow{3}{*}{ Parameter } & \multirow{3}{*}{ Pond } & & \multicolumn{5}{|c|}{ Measures of dispersion } \\
\hline & & \multirow{2}{*}{$\mathrm{X}$} & \multirow[t]{2}{*}{$\mathrm{Sd}$} & \multirow[t]{2}{*}{$\mathrm{Se}$} & \multicolumn{2}{|c|}{$\mathrm{Iv}$} & \multirow[t]{2}{*}{ CV (\%) } \\
\hline & & & & & $\mathrm{X}_{\min }$ & $\mathrm{X}_{\max }$ & \\
\hline \multirow{2}{*}{$\begin{array}{l}\text { Cholesterol } \\
(\mathrm{mg} / 100 \mathrm{~g})\end{array}$} & I & $44.11^{\alpha}$ & 3.29 & 1.34 & 39.27 & 48.26 & 7.45 \\
\hline & II & $70.12^{\beta}$ & 14.25 & 5.82 & 44.40 & 84.08 & 20.32 \\
\hline
\end{tabular}


De Francesco et al. (2004) has established that cholesterol content in trout was highly correlated with the content and type of feed ingredients. Other literature data indicate to a variability in cholesterol content, depending on genetic potential, season, age, gender, water temperature, etc (Jhaveri et al., 1984). Thus, it might be assumed that significantly higher content of cholesterol we obtained in fillets of trout in Pond II compared to Pond I might be influenced, not only by differences in type and share of feed ingredients, but by differences in water temperature, as well (Pond I- $13^{\circ} \mathrm{C}$, Pond II- $8^{\circ} \mathrm{C}$ ). According to Krzynowek et al. (1982), due to some physiological reasons, high body cholesterol was established in some fish species living in deep cold waters.

\title{
Conclusion
}

Based on the presented results, we can conclude that higher content of fat in the diet for fish in Pond II is reflected on higher content of fat in the fish fillets. However, due to the valuable fatty acids present in fatty component of fist and of some other nutrients as well, higher content of fat can be estimated as a significant parameter of fish quality and should not be considered as a negative influence of diet. Higher production results obtained in Pond II in relation to Pond I can be considered as a contribution of higher content of fat and higher energy value of the relevant diet. Consequently, higher content of cholesterol in fish from Pond II in relation to fish from Pond I might be a result not only of differences in type of feed ingredients and their share in the diet, but of the season, gender and/or water temperature as well.

\section{Acknowledgement}

This work was supported by grants from the Ministry of Education, Science and Technological Development; Republic of Serbia (projects No.TR20122 and TR31011).

\section{Uticaj ishrane na kvalitet mesa kalifornijske pastrmke (Oncorhynchus mykiss)}

\author{
D. Vranić, D. Trbović, J. Djinović-Stojanović, Ž. M. Baltić, M. Milijašević, S. Lilić, \\ A. Spirić
}




\section{Rezime}

Hrana visokog kvaliteta je jedan od najvažnijih parametara koji utiču na rast ribe, konverziju hrane i hemijski sastav mesa ribe $u$ uslovima intenzivnog uzgoja. Proučavan je uticaj dve vrste komercijalne hrane na nutritivni kvalitet i proizvodne rezultate $\mathrm{u}$ uslovima intenzivne proizvodnje kalifornijske pastrmke, $\mathrm{u}$ ribnjaku I i II. Dobijeni rezultati za proteine i masti u hrani bili su značajno veći $(p<0,001)$ u hrani II u poređenju sa hranom I. Prosečan sadržaj vode i pepela bio je značajno veći $(\mathrm{p}<0,001)$ u hrani I u odnosu na hranu II. Prosečna dužina i masa ribe bila je veća u ribnjaku I u odnosu na ribnjak II. Izracunate vrednosti za kondicioni faktor, $\mathrm{K}_{\mathrm{f}}$, ukazuju na bolje proizvodne rezultate $\mathrm{u}$ ribnjaku II $(1,81) \mathrm{u}$ odnosu na ribnjak I $(1,22)$. Nije bilo značajnih razlika $(p>0,05)$ između prosečnog sadržaja proteina i pepela u filetima ribe iz ribnjaka I $(17,43 \%$ i $1,19 \%$, respektivno) i ribnjaka II (18,69\% i 1,29\%, respektivno). Prosečni sadržaj vode bio je značajno veći, $(p<0,001)$, u filetima ribe iz ribnjaka I $(79,87 \%)$ u odnosu na filete ribe iz ribnjaka II $(75,40 \%)$. Prosečni sadržaj masti u filetima pastrmke iz ribnjaka II $(4,17 \%)$ bio je oko tri puta veći od prosečnog sadržaja masti u filetima pastrmke iz ribnjaka I $(1,41 \%),(\mathrm{p}<0,001)$. Energetska vrednost $(348,44 \mathrm{~kJ} / 100 \mathrm{~g}-$ ribnjak I i 471,38 kJ/100g - ribnjak II) je u direktnoj korelaciji sa sadržajem masti u ribi. Prosečni sadržaj holesterola u filetima pastrmke iz ribnjaka II $(70,12$ $\mathrm{mg} / 100 \mathrm{~g})$ bio je značajno veći $(\mathrm{p}<0,001)$ u odnosu na sadržaj holesterola u filetima pastrmke iz ribnjaka I $(44,11 \mathrm{mg} / 100 \mathrm{~g})$. Dobijeni rezultati ukazuju na pozitivan uticaj sadržaja masti iz hrane na sadržaj masti, energetsku vrednost i proizvodne rezultate kod kalifornijske pastrmke iz ribnjaka II. Takođe, i niža temperatura vode u ribnjaku II $\left(8^{\circ} \mathrm{C}\right)$, u poređenju sa ribnjakom I $\left(13^{\circ} \mathrm{C}\right)$, mogla je imati dodatni uticaj na bolji nutritivni kvalitet i proizvodne rezultate u ribnjaku II.

\section{References}

ALMEIDA I., MARTINS H.M., SANTOS S., FREITAS S.G., BERNARDO F. (2011): Mycobiota in feed for farmed sea bass (Dicentrarchus labrax). Biotechnology in Animal Husbandry, 27, 93-100.

BALTIĆ Ž.M., KILIBARDA N., DIMITRIJEVIĆ N. (2009): Factors significant for the shelf-life of fish and selected fish products in retail. Tehnologija mesa, 50, 166-176.

BURGER J., GOCHFELD M. (2009): Perceptions of the risks and benefits of fish consumption: Individual choices to reduce risk and increase health benefits. Environmental Research, 109, 343-349.

CABALLERO M.J., OBACH A., ROSENLUND G., MONTERO D., GISVOLD M., IZQUIERDO M.S. (2002): Impact of different dietary lipid sources on growth, 
lipid digestibility, tissue fatty acid composition and histology of rainbow trout, Oncorhynchus mykiss. Aquaculture, 214, 253-271.

CAHU C., SALEN P., DE LORGERIL M. (2004): Farmed and wild fish in the prevention of cardiovasular diseases: Assessing possible differences in lipid nutritional values. Nutrition Metabolism and Cardiovascular Diseases, 14, 34-41.

CONOR W.E. (2000): Importance of n-3 fatty acids in health and disease. American Journal of Clinical Nutrition, 71, 171S-175S.

DE FRANCESCO M., PARISI G., MEDALE F., LUPI P., KAUSHIK S., POLI B. (2004): Effect of long term feeding with a plant protein mixture based diet on growth and body/fillet quality traits of large rainbow trout (Oncorhynchus mykiss). Aquaculture, 236, 413-429.

DUBE P.N., HOSETTI B.B. (2010): Behaviour surveillance and oxygen consumption in the freshwater fish labeo rohita (hamilton) exposed to sodium cyanide. Biotechnology in Animal Husbandry, 26, 91-103.

HALILOĞLU H.I., ARAS N.M. (2002): Comparison of muscle fatty acids of three trout species (Salvelinus alpinus, Salmo trutta fario, Oncorhynchus mykiss) raised under the same conditions. Turkish Journal of Veterinary and Animal Sciences, 26, 1097-1102.

JHAVERI S.N., KARAKOLTSIDIS P.A., MONTECALVO J., CONSTANIDIS S.M. (1984): Chemical composition and protein quality of some southern New England marine species. Journal of Food Science, 49, 110-113.

KAUSHIK S.J. (1995): Nutrient requirements, supply and utilization in the contest of carp culture. Aquaculture, 129, 225-241.

KOPICOVA Z., VAVREINOVA S. (2007): Occurrence of squalene and cholesterol in various species of Czech freshwater fish. Czech Journal of Food Sciences, 25, 195-201.

KRZYNOWEK J., WIGGIN K., DONAHUE P. (1982): Cholesterol and fatty acid content in three species of crab in the northwest Atlantic. Journal of Food Science, 47, 1025-1026.

LUPATSCH I., KISSIL G.W., SKLAN D., (2001): Optimization of feeding regimes for European sea bass Dicentrarchus labrax:A factor approach. Aquaculture, 202, 289-302.

MARTINEZ F.J., GARCIA M.P., CANTERAS M., DE COSTA J., ZAMORA S. (1992): Effect of simultaneous variation of weight, density, temperature and $\mathrm{O}_{2}$ concentration on rainbow trout (O. mykiss) body composition. Reproduction Nutrition Development, 32, 105-112.

MEDALE F. (2010): Nutrition quality of fish flesh lipids as affected by farming practices. Cahiers de nutrition et de diététique, 45, 267-273.

MOREIRA A.B., VISENTAINER J.V., DE SOUZA N.E., MATSUSHITA M. (2001): Fatty acids profile and cholesterol contents of three Brazilian Brycon freshwater fishes. Journal of Food Composition and Analysis, 14, 565-574. 
NETTLETON J.A., EXLER J. (1992): Nutrients in wild and farmed fish and shellfish. Journal of Food Science, 57, 257-260.

ORBAN E., MASCI M., NEVIGATO T., DI LENA G., CASINI I., CAPRONI R., GAMBELLI L., DE ANGELIS P., RAMPACCI M. (2006): Nutritional quality and safety of whitefish (Coregonus lavaretus) from Italian lakes. Journal of Food Composition and Analysis, 19, 737-746.

PIIRONEN V., TOIVO J., LAMPI A.M. (2002): New data for cholesterol contents in meat, fish, milk, eggs and their products consumed in Finland. Journal of Food Composition and Analysis, 15, 705-713.

SHEARER K.D., (1994): Factors affecting the proximate composition of cultured fishes with emphasis on salmonids. Aquaculture, 119, 63-88.

SIDHU K.S. (2003): Health benefits and potential risks related to consumption of fish or fish oil. Regulatory Toxicology and Pharmacology, 38, 336-344.

SKALLI A., ROBIN J.H., LE BAYON N., LE DELLIOU H., PERSON-LE RUYET J. (2006): Impact of essential fatty acid deficiency and temperature on tissues' fatty acid composition of European sea bass (Dicentrarchus labrax). Aquaculture, 255, 223-232.

SPIRIĆ A., TRBOVIĆ D., VRANIĆ D., DJINOVIĆ J., PETRONIJEVIĆ R., MILIJASEVIĆ M., JANKOVIĆ S., RADICEVIĆ T. (2009): Fatty acid composition, cholesterol and total fat content in rainbow trout (Oncorhynchus mykiss) as influenced by fatty acids in diet. Tehnologija mesa, 50, 179-188. www.inmesbgd.com

TRBOVIĆ D. VRANIĆ D. DJINOVIĆ J. BOROVIĆ B. SPIRIĆ D. BABIĆ J., SPIRIĆ A. (2009): Fatty acid profile and cholesterol content in muscle tissue of one year old common carp (Cyprinus carpio) during growth. Tehnologija mesa, 50, 276-286. www.inmesbgd.com

VRANIĆ D., ĐINOVIĆ-STOJANOVIĆ J., SPIRIĆ A. (2011): Rainbow trout (Oncorhynchus Mykiss) from aquaculture - meat quality and importance in the diet. Tehnologija mesa, 52, 122-133. www.inmesbgd.com

VALENTE L.M.P., BANDARRA N. M., FIGUEIREDO-SILVA A.C., REMA P., VAZ-PIRES P., MARTINS S., PRATES J.A.M., NUNES M.L. (2007): Conjugated linoleic acid in diets for large-size rainbow trout (Oncorhynchus mykiss): effects on growth, chemical composition and sensory attributes. British Journal of Nutrition, 97, 289-297.

Received 25 September 2012; accepted for publication 20 December 2012 